\title{
Physical activity - related changes in ADMA and vWF levels in patients with type 2 diabetes: A preliminary study
}

\author{
Zanna Fiodorenko-Dumas ${ }^{1, D}$, llias Dumas ${ }^{1, A}$, Krzysztof Mastej ${ }^{2, ~ B}$, Rajmund Adamiec ${ }^{2, E, F}$ \\ ${ }^{1}$ Department of Physiotherapy, Wroclaw Medical University, Poland \\ ${ }^{2}$ Department of Angiology, Hypertension and Diabetology, Wroclaw Medical University, Poland \\ A - research concept and design; $\mathrm{B}$ - collection and/or assembly of data; $\mathrm{C}$ - data analysis and interpretation; \\ $D$ - writing the article; $E$ - critical revision of the article; $F$ - final approval of article
}

Address for correspondence

Żanna Fiodorenko-Dumas

E-mail:z.fiodorenko@poczta.onet.pl

Funding sources

None declared

Conflict of interest

None declared

Received on December 29, 2015

Revised on March 22, 2016

Accepted on April 13, 2016

DOI

10.17219/acem/62663

\section{Copyright}

Copyright by Author(s)

This is an article distributed under the terms of the

Creative Commons Attribution Non-Commercial License

(http://creativecommons.org/licenses/by-nc-nd/4.0/)

\begin{abstract}
Background. The activity and the role of methylarginine in diabetic patients are subject to continuous research. The mechanism through which diabetes or insulin resistance increases asymmetric dimethylarginine (ADMA) serum levels is not fully understood. Studies indicate increased ADMA serum levels in patients with hypertension, hypercholesterolemia and hyperhomocysteinemia.

Objectives. The aim of the study was to assess the changes in ADMA levels and its derivatives related to the current disease process, as well as the levels of selected prothrombotic factors and their changes induced by physical activity.

Material and methods. The study included 44 patients: group A (22 patients) - patients with diabetes with no vascular complications with mean age of $55.83 \pm 7.37$ years; and group B (22 patients) - healthy volunteers with the mean age of $51.16 \pm 6.39$ years. The authors' questionnaire was used to collect sociodemographic data in the study group. Physical exercise (Nordic walking) was practiced once per day for 30 min, 5 times a week. The assessment of peripheral blood parameters was performed using the ABX MICROS OT 16-parameter hematology analyzer. Additionally, chromatographic assay of serum levels of L-arginine, ADMA and symmetric dimethylarginine (SDMA) was performed.
\end{abstract}

Results. There were statistically significant differences in ADMA levels in the respondents with type 2 diabetes vs healthy volunteers after training $(0.763 \pm 0.043$ vs $0.532 \pm 0.046 ; p=0.001)$.

Conclusions. ADMA and SDMA levels in diabetic patients significantly exceeded standard values.

Key words: diabetes, atherosclerosis, physical exercise, ADMA 
Although methylarginines have been known for a long time, they have gained more interest since 1992, when Patrick Vallance et al. were the first to note that ADMA inhibits nitric oxide production. Vallance P. demonstrated that patients with end-stage renal disease show a 10-fold increase in asymmetric dimethylarginine (ADMA) serum levels. ${ }^{1}$ The researchers suggested that the premature atherosclerosis in these patients might have been partly associated with a dysfunctional L-arginine-NO system due to high ADMA levels. ${ }^{1}$ A number of studies showed increased ADMA serum levels in patients with hypertension, hypercholesterolemia, hyperhomocysteinemia, diabetes and insulin resistance. ${ }^{2-7}$

Stuhlinger et al. observed increased ADMA levels in patients with insulin resistance and in diabetic patients. ${ }^{5-7}$ In patients with type 2 diabetes, a single high-fat meal rapidly increased ADMA levels, which resulted in reduced endothelial function-related vascular relaxation. ${ }^{8}$ The mechanism through which diabetes or insulin resistance increases ADMA serum levels is not fully understood. ${ }^{9}$

Diabetes is a chronic disease associated with long-term metabolic impairment causing changes in macro- and microcirculation, which leads to irreversible damage to multiple organs. Type 2 diabetes, also known as adult-onset or noninsulin-dependent diabetes, accounts for approximately $90-95 \%$ of all cases. It results from an interaction between genetic predisposing factors and environmental factors, primarily including excessive accumulation of energy substrates. It is believed that progressive dysfunction of pancreatic beta cells and concomitant insulin resistance are responsible for the development of this condition. Chronic hyperglycemia results in the dysfunction, damage and failure of many organs, especially the eyes, kidneys, as well as cardiovascular and nervous system complications. ${ }^{10}$

Particular attention is paid to vascular complications in type 2 diabetic patients. Endothelial dysfunction is often an essential element in long-term disease. The function of free radicals and defense processes in the form of antioxidant defense systems are also important. Nitric oxide is a kind of free radicals sweeper and shows antiproliferative activity. The products of non-enzymatic glycation of proteins affect endothelial dysfunction and NO inactivation in type 2 diabetic patients. Furthermore, decreased activity of the enzyme dimethylarginine dimethylaminohydrolase (DDAH), an enzyme responsible for degrading asymmetric dimethylarginine (ADMA), which is an inhibitor of vascular NO synthesis, was observed under oxidative stress conditions. Accumulation of ADMA can contribute to vasodilator dysfunction in diabetes. ${ }^{11}$ Chronic hyperglycemia and accumulation of glycation end products can cause structural and functional impairment of platelets as well as their excessive aggregation in diabetic patients. The endothelial response involves secretion of vasomotor agents that have effects on coagulation and fibrinolysis. ${ }^{12}$ Von Willebrand factor (vWF) is a glycoprotein synthesized in the subendothelial space and megakaryocytes. It mediates platelet adhesion to endothelial cells as well as transport of coagulation factor VIII. Its levels are associated with BMI, age and hypertension. It has been shown that this factor has prognostic value in cardiovascular diseases. ${ }^{13}$

Health effects of physical activity are discussed in multiple fields of medicine. Individuals with the symptoms of metabolic syndrome are usually recommended to exercises for longer durations but with lower intensity. The American College of Sports Medicine recommends that exercise should be performed 3-5 times a week for at last 20-60 min. Regular physical activity decreases blood pressure, normalizes carbohydrate and lipid metabolism, as well as improves the endothelial function and oxygenation of tissues. These changes are very significant as they contribute to longevity and improve the comfort of life. ${ }^{14}$

Normal endothelial function ensures vascular homeostasis. Endothelial activation and the release of multiple transmitters trigger the development of atherosclerotic lesions, which are extremely dangerous in diabetic patients. ${ }^{15}$

The aim of this study was to evaluate the components of ADMA depending on the current disease process as well as to attempt to identify a relationship between the effects of physical training on changes in the levels of ADMA and its derivatives. Additionally, vWF and fibrinogen were investigated as indicators of severe prothrombotic processes in type 2 diabetic patients.

\section{Material and methods}

The study group included type 2 diabetic patients without vascular complications (group $\mathrm{A}, \mathrm{n}=22$ ), 9 females and 13 males aged 40 to 60 years (mean age $55.83 \pm 7.37$ years) and with diabetes duration of 5 up to 15 years (mean duration $5.32 \pm 1.70$ years). Patients in this group had negative results of the ischemic heart disease, normal resting ECG results, no symptoms of peripheral vascular disease and limit values of ankle brachial index $(0,9)$, average intima-media thicknesses (Avg-IMT) of carotid artery in duplex-doppler USG, normal urinary albumin excretion rate and no diabetic rethinopathy. Diabetes was diagnosed according to the current guidelines of Polish Diabetology Association.

Fig. 1. Qualification process for the study group

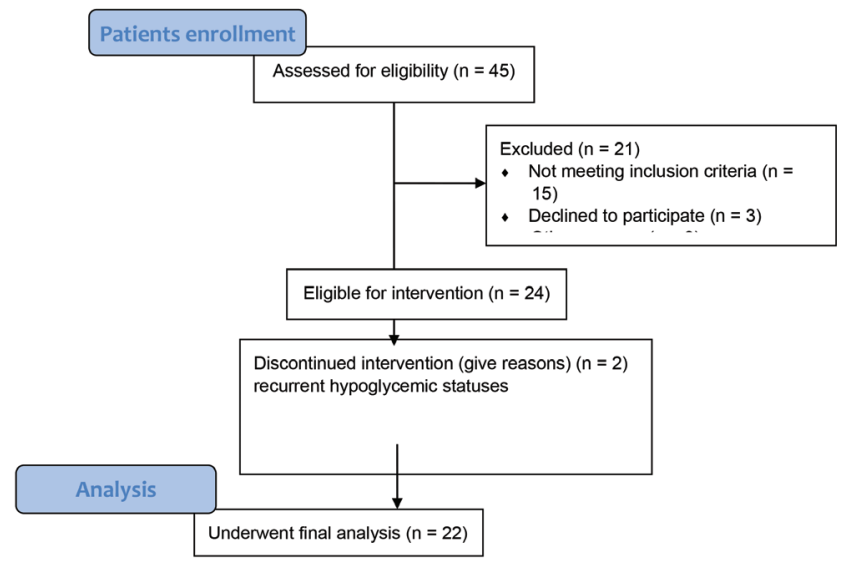


The control group included healthy volunteers (group B, $\mathrm{n}=22$ ), 12 females and 10 males aged 40 to 60 years (mean age $51.16 \pm 6.39$ years) matched with the study population in terms of age and gender.

Careful analysis of disease course, a thorough physical examination, BMI determination, repeated measuremens of blood pressure and rest electrocardiography were performed in all patients previously enrolled in the study.

The inclusion criteria were as follows:

- type 2 diabetes with duration more than 5 years;

- age above 18;

- lack of clinical symptoms of lower limbs ischemia;

- treatment with oral therapy and insulin.

Criteria for exclusion from the study:

- active infection;

- dysfunction of organ movement;

- congestive heart failure of NYHA grade > II;

- acute coronary syndrome in last 4 weeks;

- poorly controlled diabetes assessed as HbA1c > 7.5\%;

- dementia/mental disability confirmed in medical documentation or in MMSE (Mini-Mental State Examination) questionnaire. Table 1 shows the characteristics of the study groups in terms of gender, age, BMI, waist and hypertension.

Table 1. Clinical characteristics of subjects

\begin{tabular}{|c|c|c|c|}
\hline \multirow[b]{2}{*}{ Parameters } & \multicolumn{2}{|c|}{ Study groups } & \multirow[b]{2}{*}{$\begin{array}{l}\text { Significance } \\
\text { of differences }\end{array}$} \\
\hline & $\begin{array}{l}\text { type } 2 \\
\text { diabetes } \\
\text { group } \\
\text { (group A) }\end{array}$ & $\begin{array}{l}\text { control group } \\
\text { (group B) }\end{array}$ & \\
\hline N & 22 & 22 & \\
\hline Females & 9 & 12 & \\
\hline Males & 13 & 10 & \\
\hline Age (years) & $55.83 \pm 7.37$ & $51.16 \pm 6.39$ & $A$ vs $B ; n s$ \\
\hline $\begin{array}{l}\text { Time since } \\
\text { diabetes } \\
\text { diagnosis (years) }\end{array}$ & $5.32 \pm 1.70$ & & \\
\hline BMI $\left(\mathrm{kg} / \mathrm{m}^{2}\right)$ & $30.91 \pm 5.76$ & $27.66 \pm 4.27$ & A vs B; ns \\
\hline Waist (cm) & $102.00 \pm 9.84$ & $99.83 \pm 9.01$ & $A$ vs $B ; n s$ \\
\hline Hypertension (\%) & $72.7 \%$ & $18 \%$ & \\
\hline
\end{tabular}

The results are shown as mean values \pm standard deviation; ns - not statistically significant.

\section{Study design}

Eligible patients who signed informed consent participated in the uncontrolled non-randomized interventional study. Patients were instructed on how to march with trekking sticks during their hospital stay. In the next
3 days their training was supervised by a physiotherapist and corrected if needed. The level of glucose was estimated after the effort directly and an hour later. In the case of a severe decrease in glucose level, the hypoglycemic therapy was modified for the needs of exercising. The person exercising had to perform the exercises for 6 weeks, 5 days per week, for $30 \mathrm{~min}$, and to record glucose levels according to suggestions. After 6 weeks of non-supervised training, all patients underwent examination including blood test (biochemistry) during an outpatient visit. The control group was not subjected to the physical training program, but was only used as a benchmark for the compared groups of diabetic patients.

In the morning, all subjects had their venous blood collected from the elbow to assess peripheral blood cell count using the ABX MICROS OT 16-parameter instrument: hematologic, lipid metabolism, creatinine, urea, uric acid and fibrinogen levels. An additional measurement of HbA1c percentage was performed in diabetic patients.

Concentrations of ADMA, SDMA and L-arginine in blood plasma were indicated with the application of the HPLC method with fluorescent detection. SPE (solid phase) extraction method was applied in preparation of the plasma for analysis, using Varian's SCX 50 columns. Before being dispensed onto the Water Co.'s Symmetry $\mathrm{C} 18,150 \times 4.6 \mathrm{~mm}, 5 \mathrm{um}$ chromatographic column, the obtained analytes were subjected to a process of derivatisation, with OPA reagent (o- diphtalaldehyd). Test samples and standards were eluated form the column in isocratic system, with the solution of $12 \% \mathrm{v} / \mathrm{v}$ acetonitrile in K-phosphate buffer (50 mM, pH 6.6), flow $1.1 \mathrm{~mL} / \mathrm{min}$ and temperature of $35^{\circ} \mathrm{C}$. The wavelengths of the detector's excitation and emission were 340 and $450 \mathrm{~mm}$ respectively. Varian's equipment, consisting of Pro Star 240 pomp, Pro Star 363 spectrofluorescent detector, Pro Star 410 automatic sample changer and Star Chromatography Workstation software v. 6.3, was used in HPLC analysis. The obtained values are expressed in $\mu \mathrm{mol} / \mathrm{L}$.

Serum levels of vWF, the marker of vascular endothelial cell activation/destruction, were assessed in the blood sampled in the morning, from the antecubital vein into tubes containing 3.2\% sodium citrate. Within $30 \mathrm{~min}$ from the collection, the blood was centrifuged for $15 \mathrm{~min}$ at $3,000 \times$ g. The obtained plasma was stored at $-80^{\circ} \mathrm{C}$ until designation. The studies were conducted with the application of ELISA method, using Diagnostica Stago's Asserchrom $^{\circledR}$ VWF: Ag sets (catalogue number: REF 00942). The values of concentration are expressed in \% of the standard values.

Behring Coagulation Timer's equipment was used for the examination of fibrinogen concentration. The study was conducted in the laboratory of the University Clinic Hospital in accordance with the procedures applicable in the institution.

An original questionnaire, investigating sociodemographic structure of the examined groups, their age, level 
of education and place of living was used in the study. Signs of the disease, its duration, course of previous treatment and co-occurring illnesses were subjects of the analysis.

The study was approved by the local Bioethics Committee of the Medical University in

The following tests were used for statistical analysis: the Mann-Whitney U test - a nonparametric alternative to t-Student test for two independent samples. KruskalWallis test, Wilcoxon test, Spearman's nonparametric correlation coefficient. The significance level accepted in the study was $\mathrm{p}<0.05$.

\section{Results}

We found that compared with controls, diabetic patients showed higher BMI and waist circumference $\left(30.91 \pm 5.76\right.$ vs $27.66 \pm 4.27 \mathrm{~kg} / \mathrm{m}^{2} ; 102.00 \pm 9.84$ vs $99.83 \pm 9.01 \mathrm{~cm})$. The prevalence of hypertension was also higher in diabetic patients (72,7\% vs 18\%) Subjects in the control group had high normal blood pressure or grade 1 hypertension (according to ESH) lowered by pharmacological treatment (Table 1).

Statistically significant differences between diabetics and controls could be observed in relation to HbA1c (8.46 vs 6.20, $\mathrm{p}=0.01$ ), HDL (42.16 vs 54.08, $\mathrm{p}=0.0083$ ), triglycerides (212 vs $124, \mathrm{p}=0.001)$ and creatinine $(1.02$ vs $0.88, \mathrm{p}=0.031)$. Changes in the serum levels of other

Table 2. Basic laboratory parameters in patient populations

\begin{tabular}{|c|c|c|c|}
\hline \multirow[b]{2}{*}{ Parameters } & \multicolumn{2}{|c|}{ Study groups } & \multirow[b]{2}{*}{$\begin{array}{l}\text { Significance } \\
\text { of differences }\end{array}$} \\
\hline & $\begin{array}{c}\text { type } 2 \\
\text { diabetic } \\
\text { patients } \\
\text { (group A) }\end{array}$ & $\begin{array}{l}\text { controls } \\
\text { (group B) }\end{array}$ & \\
\hline N & 22 & 22 & \\
\hline $\begin{array}{l}\text { Leukocytosis } \\
\text { (thousand/ } \mu \mathrm{L} \text { ) }\end{array}$ & $7.63 \pm 1.83$ & $5.68 \pm 1.32$ & A vs B; ns \\
\hline 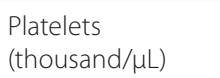 & $204.41 \pm 38.44$ & $232.5 \pm 65.48$ & A vs B; ns \\
\hline $\begin{array}{l}\text { Fasting glycaemia } \\
(\mathrm{mg} / \mathrm{dL})\end{array}$ & $153.83 \pm 25.95$ & $96.91 \pm 5.58$ & A vs B; ns \\
\hline HbA1c (\%) & $\begin{array}{l}8.46 \pm 3.06 \\
{[\operatorname{IRQ} 6 ; 6.5 ; 7]}\end{array}$ & $6.20 \pm 0.83$ & $A$ vs $B ; p=0.01$ \\
\hline $\begin{array}{l}\text { Total cholesterol } \\
(\mathrm{mg} / \mathrm{dL})\end{array}$ & $207.833 \pm 51.742$ & $200.41 \pm 43.37$ & $A$ vs $B ; n s$ \\
\hline $\mathrm{HDL}(\mathrm{mg} / \mathrm{dL})$ & $42.16 \pm 4.93$ & $54.08 \pm 12.63$ & $\begin{array}{c}\text { A vs B; } \\
p=0.0083\end{array}$ \\
\hline LDL (mg/dL) & $122.41 \pm 38.36$ & $131,16 \pm 35,81$ & $A$ vs $B ; n s$ \\
\hline $\begin{array}{l}\text { Triglycerides } \\
(\mathrm{mg} / \mathrm{dL})\end{array}$ & $212 \pm 103.69$ & $124 \pm 48.66$ & $\begin{array}{c}A \text { vs B; } \\
p=0.001\end{array}$ \\
\hline $\begin{array}{l}\text { Creatinine } \\
(\mathrm{mg} / \mathrm{dL})\end{array}$ & $1.02 \pm 0.19$ & $0.88 \pm 0.12$ & $\begin{array}{c}\text { A vs B; } \\
p=0.031\end{array}$ \\
\hline
\end{tabular}

The results are shown as mean values \pm standard deviation; ns - not statistically significant.
Table 3. ADMA and selected prothrombotic parameters in the groups of patients

\begin{tabular}{|c|c|c|c|}
\hline \multirow[b]{2}{*}{ Parameters } & \multicolumn{2}{|c|}{ Study groups } & \multirow[b]{2}{*}{$\begin{array}{l}\text { Significance } \\
\text { of differences }\end{array}$} \\
\hline & $\begin{array}{c}\text { type } 2 \\
\text { diabetic } \\
\text { patients } \\
\text { (group A) }\end{array}$ & $\begin{array}{l}\text { controls } \\
\text { (group B) }\end{array}$ & \\
\hline ADMA ( $\mu \mathrm{mol} / \mathrm{L})$ & $0.794 \pm 0.050$ & $0.532 \pm 0.046$ & $\begin{array}{c}A \text { vs B; } \\
p=0.001\end{array}$ \\
\hline SDMA ( $\mu \mathrm{mol} / \mathrm{L})$ & $0.842 \pm 0.103$ & $0.443 \pm 0.071$ & $\begin{array}{c}A \text { vs B; } \\
p=0.001\end{array}$ \\
\hline $\begin{array}{l}\text { L-arginine } \\
(\mu \mathrm{mol} / \mathrm{L})\end{array}$ & $70.620 \pm 15.413$ & $82.760 \pm 24.901$ & $A$ vs B; ns \\
\hline VWF (\%) & $201.24 \pm 87.28$ & $148.06 \pm 90.34$ & $\begin{array}{l}\text { A vs B; } \\
p=0.03\end{array}$ \\
\hline Fibrinogen (g/L) & $3.62 \pm 0.60$ & $2.53 \pm 0.43$ & A vs B; ns \\
\hline
\end{tabular}

The results are shown as mean values \pm standard deviation; ns - not statistically significant.

biochemical markers were within the range of generally accepted laboratory standards (Table 2).

ADMA and SDMA serum levels in diabetic patients were statistically significantly higher compared to controls $(\mathrm{p}=0.001)$. L-arginine levels in patients were lower than those in controls, but the differences did not reach statistical significance. There was a statistically significant difference in vWF between the groups ( $\mathrm{p}=0.03$ ). The concentration of von Willebrand factor was higher in the group of patients with type-2 diabetes. (Table 3).

Among the selected laboratory assessments of metabolic control of diabetes, statistical significance was reached by a negative correlation related to ADMA and HDL cholesterol levels (correlation coefficient -0.615, $\mathrm{p}=0.05$ ). There was a statistically significant correlation between SDMA and creatinine levels (correlation coefficient $0.582, \mathrm{p}=0.05$ ). The other evaluated biochemical parameters did not show any significant relationship with ADMA in the study groups (Table 4).

In the group of patients, ADMA serum levels tended to decrease due to physical training, but the difference was statistically insignificant; the levels were still higher compared to those in controls, but the difference from the standard was statistically significantly lower compared to baseline $(\mathrm{p}=0.01)$. Physical exercise had greater effects on SDMA reduction, and the difference from the values before physical training was statistically significant in group A $(\mathrm{p}=0.04)$. A significant training-related decrease in vWF levels in the group of patients $(\mathrm{p}=0.01)$ resulted in data similar to those obtained in the control group. In the case of fibrinogen, the difference between the physical exercise group and healthy volunteers was not statistically significant (Table 5). 
Table 4. Relationship between ADMA and laboratory parameters

\begin{tabular}{|c|c|c|c|c|c|c|}
\hline Study groups & \multicolumn{3}{|c|}{ Type 2 diabetic patients (group A) } & \multicolumn{3}{|c|}{ Controls (group B) } \\
\hline N & & 22 & & & 22 & \\
\hline Parameter & ADMA ( $\mu \mathrm{mol} / \mathrm{L})$ & SDMA ( $\mu \mathrm{mol} / \mathrm{L})$ & $\begin{array}{l}\text { L-arginine } \\
(\mu \mathrm{mol} / \mathrm{L})\end{array}$ & ADMA (umol/L) & SDMA ( $\mu \mathrm{mol} / \mathrm{L})$ & $\begin{array}{c}\text { L-arginine } \\
(\mu \mathrm{mol} / \mathrm{L})\end{array}$ \\
\hline Total cholesterol (mg/dL) & -.151 & .431 & -.217 & -.204 & .266 & .301 \\
\hline $\mathrm{HDL}(\mathrm{mg} / \mathrm{dL})$ & $-.615^{*}$ & -.113 & .088 & -.102 & .470 & .144 \\
\hline LDL (mg/dL) & .007 & .476 & -.091 & -.394 & -.105 & .503 \\
\hline $\mathrm{TG}(\mathrm{mg} / \mathrm{dL})$ & -.490 & .259 & -.371 & .106 & .252 & -.315 \\
\hline Glycaemia (mg/dL) & -.147 & .266 & -.406 & .155 & -.232 & .014 \\
\hline HbA1c (\%) & -.228 & .021 & -.175 & .131 & -.285 & -.214 \\
\hline Creatinine (mg/dL) & -.519 & $.582^{*}$ & -.144 & .123 & -.389 & -.221 \\
\hline Leucocytes (thousand/ $\mu \mathrm{L}$ ) & .154 & -.252 & .441 & -.046 & -.011 & -.266 \\
\hline Uric acid (mg/dL) & -.326 & .411 & -.365 & .071 & -.130 & -.018 \\
\hline Albuminuria (g/dL) & .126 & .315 & .133 & .394 & .357 & 0.000 \\
\hline
\end{tabular}

The results are shown as mean values \pm standard deviation; ns - not statistically significant.

\section{Discussion}

Asymmetric dimethylarginine (ADMA) is a naturally occurring amino acid in the human body. It is detected in blood serum and multiple organs, and is excreted in the urine. Methylarginines, which are similar to L-arginine, but differ in the presence of 1 or 2 methyl groups, are strong endogenous inhibitors of nitric oxide - a strong vasodilator and anti-atherogenic factor. So far, it has not been established whether ADMA generation is constant or if the increased PRMT (protein methyltransferase) expression leads to a significant increase in ADMA serum levels. Also, it is not clear whether increased protein catabolism has any effects on ADMA serum levels. According to literature reports, the route of methylated arginine excretion is also responsible for the impairment of the excretory route, which is the main cause of increased ADMA and SDMA levels in patients with chronic renal impairment. It is estimated that humans generate approximately $300 \mu \mathrm{mol}$ of ADMA per day, of which about $250 \mu \mathrm{mol}$ is metabolized by DDAH (dimethylarginine dimethylaminohydrolase), and $50 \mu \mathrm{mol}$ is excreted in the urine. ${ }^{16}$

Traditional risk factors for atherosclerosis, which can lead to vascular endothelial damage, are based on continuous generation of nitric oxide (NO). ADMA, which blocks its formation, initiates and maintains atherosclerotic development. Increased ADMA levels in diabetic patients indicate an ongoing atherosclerotic process. ${ }^{17}$
Both macro- and microangiopathic complications have significant effects on the quality of life and functioning of patients, acting as a predictor of further life duration. Our study showed increased ADMA serum levels in type 2 diabetic patients $(0.794$ vs $0.532, \mathrm{p}=0.001)$ compared to controls. Despite the fact that SDMA has no inhibitory effects on nitric oxide synthase (NOS) and is almost fully excreted via the kidneys, its levels in the study group were significantly higher compared to healthy volunteers (0.842 vs $0.443, \mathrm{p}=0.001$ ).

Abbasi and Lin also confirmed increased ADMA levels in patients with insulin resistance as well as in diabetic patients. ${ }^{6}$ Although the mechanism underlying the increase in ADMA in diabetic patients is not fully understood, it is assumed that glucose has inhibitory effects on DDAH activity. In the study by Achan, whose aim was to assess the physiological processes following ADMA administration in healthy volunteers (achieving a 3-fold increase in ADMA serum levels), reduced heart rate, decreased ejection fraction, increased peripheral resistance and elevated blood pressure were observed. ${ }^{18}$

In our study, a significant relationship between HDL and ADMA may be observed in the analysis of cholesterol fractions relative to ADMA and its derivatives. This is a negative correlation of $-0.615(\mathrm{p}=0.05)$. No other correlations related to these variables were found. Anti-atherogenic functioning of HDL cholesterol involves antiphlogistic, antioxidative, and vascular diastolic mechanisms and adjusting the function of vascular endothelium. 
Table 5. The effects of physical training on ADMA parameters and prothrombotic factors

\begin{tabular}{|c|c|c|c|c|}
\hline & Parameter & $\begin{array}{c}\text { Type } 2 \text { diabetic patients } \\
\text { (group A) }\end{array}$ & Controls (group B) & $\begin{array}{l}\text { significance of } \\
\text { differences }\end{array}$ \\
\hline N & & 22 & 22 & \\
\hline & before training & $0.794 \pm 0.050$ & & \\
\hline ADMA ( $\mu \mathrm{mol} / \mathrm{L})$ & after training & $0.763 \pm 0.043$ & $0.532 \pm 0.046$ & $p=0.01$ \\
\hline & significance of differences & Ns & & \\
\hline & before training & $0.842 \pm 0.103$ & & \\
\hline $\mathrm{sDMA}(\mu \mathrm{mol} / \mathrm{L})$ & after training & $0.733 \pm 0.090$ & $0.443 \pm 0.071$ & $p=0.01$ \\
\hline & significance of differences & $p=0.04$ & & \\
\hline & before training & $70.620 \pm 15.413$ & & \\
\hline L-arginine $(\mu \mathrm{mol} / \mathrm{L})$ & after training & $79.229 \pm 12.830$ & $82.760 \pm 24.901$ & ns \\
\hline & significance of differences & $p=0.05$ & & \\
\hline & before training & $201.24 \pm 87.28$ & & \\
\hline VWF(\%) & after training & $163.06 \pm 55.13$ & $148.06 \pm 90.34$ & ns \\
\hline & significance of differences & $p=0.01$ & & \\
\hline & before training & $3.62 \pm 0.60$ & & \\
\hline Fibrinogen ( $\mathrm{g} / \mathrm{L}$ ) & after training & $3.24 \pm 0.72$ & $2.53 \pm 0.43$ & ns \\
\hline & significance of differences & ns & & \\
\hline
\end{tabular}

The results are shown as mean values \pm standard deviation; ns - not statistically significant.

The results of the Treating to New Targets (TNT) study testify to the significant role of this fraction of lipids in inhibition of atherogenesis. The analysis of the data showed that despite the decrease of the LDL cholesterol concentration below $70 \mathrm{mg} / \mathrm{dL}$, there still exists a high risk of cardio-vascular disease connected with the low concentration of HDL cholesterol - the difference in the risk between persons from the lowest and the highest quintile of HDL cholesterol concentration, after controlling for sex, age, BMI, tobacco smoking, glucose, triglycerides, diabetes, myocardial infarction, and arterial hypertension, was 39\%, independently from the treatment with statins. ${ }^{3,19}$ The quoted authors' observations were confirmed by the present surveys. In both groups of analyzed patients, the concentration of HDL-fraction cholesterol was significantly lower in comparison with healthy persons $(\mathrm{p}=0.0083 ; \mathrm{p}=0.0087)$. The values of the standard triglyceride concentration in the blood serum were also higher in these patients $(\mathrm{p}=0.001 ; \mathrm{p}=0.015)$.

Chan et al. demonstrated in their studies that LDL cholesterol, by increasing the activity of type I protein meth- yltransferase, enhances ADMA production, whereas by decreasing the activity of DDAH, it reduces its metabolism. ${ }^{19}$ These mechanisms account for increased ADMA levels in patients with hypercholesterolemia.

Vascular endothelium, which plays a significant role in the pathogenesis of vascular lesions in the course of diabetes, not only acts as a specific barrier, but, through multiple interactions at the molecular level, it primarily regulates homeostasis and normal blood flow, as well as proliferation of the endothelial cells of vascular walls; it also affects vascular wall permeability and the inflammatory response via multiple mediators. ${ }^{20}$ Its damage results in the release of substances considered to be an indicator of endothelial function, such as vWF, into the bloodstream. It is responsible for proper adhesion of platelets to the subendothelium and protects factor VIII by forming inactive complexes with this factor. Kotschy et al. observed higher levels of vWF in a group of diabetic patients compared to controls $(\mathrm{p}<0.000){ }^{21}$ There was no such relationship for gender or age of the subjects. As in the case of concomitant proliferative retinopathy, hypertension or 
smoking tobacco had no significant effects on vWF levels in diabetic patients.

Our results confirmed the above-mentioned relationships. The vWF values were higher in diabetic patients than in healthy volunteers (201.24 vs $148.06, \mathrm{p}=0.03$ ), and the differences were statistically significant, which may indicate vascular endothelial cell damage. Similar results were obtained by Fujiwara et al., who observed higher vWF levels in patients with type 2 diabetes additionally complicated by retinopathy. ${ }^{22}$

There are various metabolic changes during physical exercise, depending on training duration. ${ }^{23}$ At each training stage, there is an increase in the energy demand in the working muscles, the source of energy changes - initially glycogen is a source of energy, but after approximately 30 min it is replaced by substrates from blood and free fatty acids. Long-term improvement in glycemic control in patients who exercise systematically is more likely to result from cumulative effects of the individual training sessions than from overall improvement in the fitness level of the patient. ${ }^{23}$

Our results confirmed the reduction in vWF levels (201.24 vs $163.06 \%$; $\mathrm{p}=0.01$ ) due to physical training. The differences were statistically significant. Intensive, exhausting training causes hypercoagulation, especially in individuals who do not train regularly. This results from the overproduction of thrombin, increased aggregation of platelets as well as increased activity of coagulation factors, especially factor VIII and vWF. Increased fibrinolytic activity was also observed following physical exercise. However, these changes were reversible. At rest, these parameters returned to normal or even decreased. Considering the long-term physical exercise, adaptive changes may reduce the risk of cardiovascular events and thrombosis. ${ }^{24-26}$ Own studies did not prove, as programmed physical training influenced the results of ADMA in the essential way. The values of this parameter fell down from 0.794 imperceptibly \pm 0.050 vs $0.763 \pm 0.043 \mu \mathrm{mol} / \mathrm{L}$. Schlager et al. achieved different results in their study. ${ }^{27}$ Physical training lasting 6 months reduced the ADMA level simultaneously enlarging angiogenesis and improving the endothelial function. Teplan et al. reached similar results. ${ }^{28}$ They noticed the downgrade of ADMA from $3.50 \pm 0.45$ vs $2.11 \pm 0.35$ $\mu \mathrm{mol} / \mathrm{L}$ in patients after kidney transplant who exercised regularly. ${ }^{28}$ Also, Mittermayer et al. confirmed the downgrade of this parameter after regular exercise. ${ }^{29}$ Our studies showed changes in SDMA and L-arginine levels, which occurred due to planned, physical training. SDMA decreased from 0.842 to $0.733(\mathrm{p}=0.04)$ and the changes were significant both in the patient group and when compared to controls. L-arginine level increased from 70.620 to 79.229 ( $\mathrm{p}=0.05)$. Fibrinogen values slightly decreased and did not show statistical significance when the physical exercise group was compared to the healthy volunteers. Since it is impossible to compare the obtained results, fur- ther exploration of the subject matter with a higher number of respondents as well as an analysis of other, also important, variables is necessary. It may be assumed, based on the changes in the levels of endothelial homeostatic processes, that the severity of inflammatory processes decreased, and the additional modification of the lipid process could only have beneficial effects on the human organism. ${ }^{30,31}$

\section{Conclusions}

Increased concentration of ADMA and negative correlation with the HDL rigor confirm relationship of disorders in endothelial function with incorrect metabolism of lipids at patients with type 2 diabetes.

The decrease of vWF level in the consecution of regular physical training shows on his profitable influence on the functional condition

We demonstrated decreased severity of thrombotic processes (vWF) resulting from regular physical activity, which had additional positive effects on the metabolic profile of the disease.

\section{References}

1. Vallance $\mathrm{P}$, Leone $\mathrm{A}$, Calver A, et al. Accumulation of an endogenous inhibitor of nitric oxide synthesis in chronic renal failure. Lancet. 1992;339:572.

2. Surdacki A, Nowicki M, Sadmann J, et al. Reduced urinary excretion of nitric oxide metabolites and increased plasma levels of asymmetric dimethylarginine in men with essential hypertension. J Cardiovasc Pharmacol. 1999;33:652.

3. Böger RH, Bode-Böger SM, Szuba A, et al. Asymmetric dimethylarginine (ADMA): A novel risk factor for endothelial dysfunction: Its role in hypercholesterolemia. Circulation. 1998;98:1842.

4. Sydow K, Schwedhelm E, Arakawa N, et al. ADMA and oxidative stress are responsible for endothelial dysfunction in hyperhomocyst(e)inemia: Effects of L-arginine and B vitamins. Cardiovasc Res. 2003;57:244.

5. Abbasi F, Asagni T, Cooke JP, et al. Plasma concentration of asymmetric dimethylarginine are increased in patient with type 2 diabetes mellitus. Am J Cardiol. 2001;88:1201.

6. Lin KY, Ito A, Asagami $\mathrm{T}$, et al. Impaired nitric oxide synthase pathway in diabetes mellitus. Role of asymmetric dimethylarginine and dimethyl-arginine dimethylaminohydrolase. Circulation. 2002;106:987.

7. Stuhlinger MC, Abbasi F, Chu JW, et al. Relationship between insulin resistance and an endogenous nitric oxide synthase inhibitor. JAMA. 2002;287:1420.

8. Fard A, Tuck CH, Donis JA, et al. Acute elevation of plasma asymmetric dimethylarginine and impaired endothelial function in response to a high-fat meal in patients with type 2 diabetes. Arterioscler Thromb Vasc Biol. 2000;20:2039.

9. Vallance P, Leiper J. Cardiovascular biology of the asymmetric dimethylarginine: dimethylarginine dimethylaminohydrolase pathway. Arterioscler Thromb Vasc Biol. 2004;24:1023.

10. Chełmińska K. Wpływ wysiłku fizycznego na występowanie i przebieg cukrzycy. Przegl Lek. 1997;54:62-66.

11. Cooke JP. Does ADMA cause endothelial dysfunction? Arterioscler Thromb Vasc Biol. 2000;20:2032.

12. MacAllister RJ, Rambausek $\mathrm{MH}$, Vallance $\mathrm{P}$, et al. Concentration of dimethyl-L-arginine in the plasma of patient with end-stage renal failure. Nephrol Dial Transplant. 1996;11:2449.

13. Nadar S, Blann AD, Lip GYH. Endothelial dysfunction. Methods of assessment and application to hypertension. Curr Pharm Des. 2004;10:3591-3605. 
14. Czech A, Tatoń J, Bernas M, Łaz R, Szczeklik-Kumala Z. Tolerancja wysiłków fizycznych jako czynnik determinujący stosowanie leczenia treningiem fizycznym u osób z cukrzycą. Przew Lek. 2001;4(5):37-43.

15. Kraśnicki P, Proniewska-Skrętek E, Dmuchowska DA, Dobrzycki $S$, Mariak Z. Asymetryczna dimetyloarginina (ADMA) jako marker zaburzeń przepływu krwi przez naczynia zaopatrujące gałkę oczną u pacjentów z cukrzycą typu 2 i chorobą niedokrwienną serca. Magazyn Lekarza Okulisty. 2009;3(6):325-330.

16. Cooke JP. Asymmetrical dimethylarginine. The über marker? Circulation. 2004;109:1813.

17. Horl WH. Uremic toxins: New aspects. J Nephrol. 2000;13(Suppl. 3):S83.

18. Achan V, Broadhead M, Malaki M, et al. Asymmetric dimethylarginine causes hypertension and cardiac dysfunction in humans and is actively metabolized by dimethylarginine dimethylaminohydrolase. Arterioscler Tromb Vasc Biol. 2003;23:1455.

19. Chan JR, Böger RH, Bode-Böger SM, et al. Asymmetric dimethylarginine increases mononuclear cell adhesiveness in hypercholesterolemic humans. Arterioscler Thromb Vasc Biol. 2000;20:1040.

20. Neubauer-Geryk J, Bieniaszewski L. Metody oceny funkcji śródbłonka. Wazodylatacja tętnicy ramiennej po niedokrwieniu, Choroby Serca i Naczyń. 2007;4(4):190-196.

21. Kotschy M, Polaszewska-Muszyńska M, Będowska-Gontarz W, Sikorska Z, Moskal S. Von Willebrand factor and tissue plasminogen activator as vascular endothelial markers in diabetes type 2 . Acta Angiol. 2003;9(2):63-69.

22. Fujiwara Y, Tagami S, Kawakami Y. Circulating thrombomodulin and hematological alterations in type 2 diabetic patients with retinopathy. J Atheroscler Thromb. 1998;5:21-28.

23. Otto Buczkowska E, Jarosz-Chobot P. Znaczenie leczniczego treningu fizycznego w leczeniu cukrzycy. Ped Endocrinol Diab Metab. 1999;5(1):35-38.

24. Wierusz-Wysocka B, Zozulińska D. Wybrane mechanizmy przewlekłych powikłań cukrzycy. Diabetol Pol. 2000;7:193-197.

25. Morise T, Takeuchi Y, Kawano M, Koni I. Increased plasma levels of immunoreactive endothelin and von Willebrand factor in NIDDM patients. Diabetes Care. 1995;18(1):87-89.

26. Pirsco D, Francalanci I, Filippini M, Hagi MI. Physical exercise and hemostasis. Int J Clin Lab Res. 1994;24(3):125-131.

27. Schlager O, Giurgea A, Schuhfried O, et al. Exercise training increases endothelial progenitor cells and decreases asymmetric dimethylarginine in peripheral arterial disease: A randomized controlled trial. Atherosclerosis. 2011;217(1):240-248.

28. Teplan V, Mahrova A, Pitha J, et al. Early exercise training after renal transplantation and asymmetric dimethylarginine: The effect of obesity. Kidney \& Blood Pressure Research. 2014;39(4):289-298.

29. Mittermayer F, Pleiner J, Krzyzanowska K, Wiesinger G, Francesconi M, Wolzt M. Regular physical exercise normalizes elevated asymmetrical dimethylarginine concentrations in patients with type 1 diabetes mellitus. Wien Klin Wochenschr. 2005;117(23$-24): 816-820$

30. Peirce NS. Diabetes and exercise. Br J Sports Med. 1999;33(3): $161-172$.

31. Lippi G, Maffulli N. Biological influence of physical exercise on hemostasis. Tromb Hemost. 2009;35(3):269-276. 